\section{LIFE AND ENVIRONMENT ON THE BED OF THE SEA}

THIS was the subject of Prof. C. M. Yonge's presidential address to Section D (Zoology). In his opening remarks he reminded those present that the demersal invertebrates of shallow seas are divisible into epifaunal and infaunal animals, the former living largely on hard, and the latter within soft, substrata. While the first have diverse feeding habits they are less specialized than members of the burrowing infauna which are, however, restricted to suspension feeders, deposit feeders and carnivores. Abundant in all latitudes, the infauna is only about one-fourth as rich in species as the epifauna, which is most diverse in the tropics.

Initial populations were probably either epifaunal or pelagic and the establishment of soft substrates must long have preceded the evolution of organisms able to exploit their possibilities and add to these by formation of organic detritus. In shallow water the finer grades of bottom material came increasingly to represent food as well as shelter. But, being largely without oxygen and demanding elaborate burrows, their invasion was doubtless the final stage in colonization of the sea bed.

Sponges and coelenterates are essentially epifauna] groups, the latter exploiting this habitat with supreme success culminating in the formation of coral reefs. Annelids, crustaceans and echinoderms are also largely epifaunal, although many have invaded soft substrates. The Mollusca were also primitively epifaunal and, at least in so far as they were ancestral to modern classes, more simply constructed than Neopilina.

Of these, the Gastropoda represent the major epifaunal, and the Bivalvia the major infaunal, class. The Archaeogastropoda retain the basic habit but evolution of structure in the Mesogastropoda permits invasion of soft substrata, for example, the ciliary feeding Trichotropis living on bottoms largely of dead shells while Turritella and Aporrhais, respectively suspension and deposit feeders, burrow in mud. Carnivorous mesogastropods, notably naticoids, invade soft substrates feeding largely on bivalves. This is also true of some Opisthobranchia.

The Bivalvia are the supreme exponents of the infaunal habit. Lateral compression renders penetration easy, enclosure and then loss of the head by the mantle/shell makes them obligatory suspension or deposit feeders. Initially burrowing superficially with anterior inhalant current, movement of this posteriorly with development of siphons enabled bivalves to exploit all soft substrates. Deep burrowers evolved independently in four suspension. feeding groups as well as in the deposit-feeding Tellinacea. From the former came rock borers such as Platyodon.

Exploitation of the epifaunal habitat came by retention of the initially post-larval byssal apparatus. Such attachment of the body led to changes in its proportions, to heteromyarianism as in mussels (Mytilidae) and to monomyarianism as in scallops (Pectinidae). This could lead to cementation (attachment by mantle/shell) as in oysters (Ostraeidae) or to freedom as in many scallops, that is, to epifaunal life on soft as well as hard substrata. The infaunal habit may be regained by byssally attached heteromyarians either by boring into rock, mechanically (Botula) or chemically (Lithophaga), the shell be- coming secondarily symmetrical, or by vertical attachment within soft substrates as in the Pinnidae.

\section{TECHNOLOGY AND GEOGRAPHY}

HE presidential address to Section E (Geography) by Prof. S. H. Beaver was entitled "Technology and Geography", and emphasized the fact that all human activity takes place in an environment which has three major aspects, physical, technical and economic (including social). Each of these is subject to change-though the first is the most stable-and each will vary in its importance according to the activity.

The physical environment comprises the underlying geology, the soil and vegetation cover, the surface configuration of the land, and the climate. It is virtually immutable by man, though to an increasing extent modern engineering techniques are making it possible, if not to remove mountains, in any event to divert rivers through their watersheds and to carve up the land surface with very striking effect.

The economic environment is of immense importance in almost all human activity, for very few parts of the world are completely without money or other tokens of exchange. All productive activity must be related to costs of production (including interest on borrowed capital, costs of raw materials, fuel and power, transport, labour) selling prices, tariffs and taxes. Here, clearly, is an ever-changing environment and one capable of much manipulation by man.

The technical environment comprises the technical aids which are available to assist in the process of land occupation and development of resources. Here is an environment of great complexity, from the primitive digging-stick and water-wheel to the blast furnace, the chemical insecticide and atomic energy; an environment which varies immensely from time to time and from place to place.

The interest which the technical environment has for the geographer is concerned largely with the changes in geographical values which are brought about by inventions and innovations. Within the total geographical environment all the many components have their respective values in relation to any particular activity at any given time. Alter one of the components and the relative values of others will change.

The examples given in the address-mainly from the field of mineral-working and mineral-using industries, but including also electric power and motorcar manufact ure--seem to lead to the conclusion that rather than emancipating man from control by his environment, technioal advancement often works the other way, narrowing appreciably the variety of locations in which the more advanced techniques may be praotised. Thus the widespread distribution of the pre-Industrial Revolution iron industry was considerably reduced by the invention of smelting by coke, for only a few British coalfields possessed coking coals and iron-ores in the same strata; the invention of steel-making processes narrowed the range of possible localities still further, while with the development of the modern integrated works, increasingly dependent on foreign iron ores, only a mere handful of possible sites remains, as the postwar history of the industry well shows.

Old-fashioned thermal-electric generating stations were widespread, depending largely on the distribu- 